\title{
Evaluation of the uniformity and stability of T-DNA integration and gene expression in transgenic apple plants
}

\author{
Henryk Flachowsky \\ Institute of Fruit Breeding \\ Federal Centre for Breeding Research on Cultivated Plants \\ Pillnitzer Platz 3a \\ D-01326 Dresden, Germany \\ Tel: 493512616215 \\ Fax: 493512616213 \\ E-mail: h.flachowsky@bafz.de \\ Marko Riedel \\ Institute of Fruit Breeding \\ Federal Centre for Breeding Research on Cultivated Plants \\ Pillnitzer Platz 3a \\ D-01326 Dresden, Germany \\ Tel: 495312994429 \\ Fax: 495312993009 \\ E-mail: m.riedel@bba.de \\ Stefanie Reim \\ Institute of Fruit Breeding \\ Federal Centre for Breeding Research on Cultivated Plants \\ Pillnitzer Platz 3a, \\ D-01326 Dresden, Germany \\ Tel: 493514526171 \\ Magda-Viola Hanke* \\ Institute of Fruit Breeding \\ Federal Centre for Breeding Research on Cultivated Plants \\ Pillnitzer Platz 3a \\ D-01326 Dresden, Germany \\ Tel: 493512616214 \\ Fax: 4903512616213 \\ E-mail: v.hanke@bafz.de
}

Financial support: This research was funded in part by the Federal Ministry for Education and Research (BMBF) and the Saxon State, Ministry of Environment and Agriculture (SMUL).

Keywords: Agrobacterium tumefaciens, apple, chimeric tissue, gene silencing, Malus domestica, T-DNA leakage.

Abbreviations:

$$
\begin{aligned}
& \text { attE: attacin E gene } \\
& \text { ELISA: Enzyme Linked Immunosorbent Assay } \\
& \text { guSA: } \beta \text {-glucuronidase gene } \\
& \text { GUS: glucuronidase } \\
& \text { nos: nopaline synthase gene } \\
& \text { nptII: neomycin phosphotransferase II gene } \\
& \text { NPTII: neomycin phosphotransferase II protein } \\
& \text { PCR: polymerase chain reaction } \\
& \text { PTGS: post-transcriptional gene silencing } \\
& \text { RNA: ribonucleic acid } \\
& \text { RT-PCR: reverse transcription PCR } \\
& \text { T-DNA: transfer DNA } \\
& \text { TGS: transcriptional gene silencing } \\
& \text { UTR: untranslated region }
\end{aligned}
$$

The generation of transgenic apple plants relies on the molecular analysis of transgene integration and expression based on polymerase chain reaction (PCR) analysis, blotting techniques and enzymatic assays on vitro leaves of putative transgenic regenerates. In order to assess the uniformity and the stability of transfer DNA (T-DNA) integration and gene expression, we studied 26 transgenic apple lines carrying the attacin $\mathrm{E}$

${ }^{*}$ Corresponding author 
gene from Hyalophora cecropia, the $\beta$-glucuronidase gene, and the nptII gene. Plants were evaluated using standard molecular techniques, such as PCR, Southern blot, reverse transcription PCR (RT-PCR) and Enzyme Linked Immunosorbent Assay (ELISA), and propagated in vitro on non-selective antibiotic-free media for four years to mimic natural conditions in the field. In some $T$-lines transgene integration and expression did not remain stable; differences were also found between distinct plants of a single $T$-line. Individual plants with partially or completely silenced transgenes were identified as well as plants with nondetectable T-DNA. Several lines appeared chimeric or partially silenced. Although most molecular techniques can reliably detect the presence of transgenic cells, they often fail to detect mixtures of transformed and nontransformed cells, or cells with silenced transgenes. This should be taken into consideration, especially in the case of vegetatively propagated trees, where nontransformed or silenced plant parts could mistakenly be used as propagation material.

Genetic engineering becomes increasingly important as a tool in plant breeding. Mainly in plants with a long generation and breeding cycle, such as apple, biotechnology and especially genetic engineering can provide an opportunity to overcome the limitations of conventional breeding methods (Gartland et al. 2003) and to establish genotypes with discrete genetic changes in established cultivars (Briviba et al. 2004). Among others, the enhancement of resistance to important pathogens is a major objective of genetic engineering in apple (Reim et al. 2006). In this context, stably transformed lines with a high level of transgene expression during the entire life cycle of the tree are a prerequisite for introduction of these trees into fruit production (Reim and Hanke, 2004).

The routine generation of transgenic plants involves analysis of transgene integration into the host genome as well as the evaluation of the transgene expression using standard molecular techniques such as polymerase chain reaction (PCR), Southern blot, reverse transcription PCR (RT-PCR) and Enzyme Linked Immunosorbent Assay (ELISA) or Western blot. These techniques are based on the usage of a mixture of leaf cells per plant for analyses. The presence of some transgenic cells results in a positive detection of the transgene and the transgene protein, respectively. Plants with detectable fragments of the expected size and acceptable values of transgene protein are labeled as transgenic. However, the potential presence of cells without the transgenic trait remains undetected. This fact is unproblematic for marker genes like nptII, because cells without nptII expression are not enabled to grow under selection pressure. Otherwise, no selection pressure is performed for the gene of interest. Cells not expressing the gene of interest will survive, and both cell types are enabled to grow. In that case, it is difficult to obtain homogenic expression data. It has been described in different studies that lines with a desired level of transgene expression have lost the transgenic trait in subsequent generations (Butaye et al. 2005). Similar problems could be expected for later stages of tree growth and development. Mainly during glasshouse and open field cultivation, no selection pressure is performed for the marker gene as well as for the gene of interest. During that time, the mitotic segregation of chimeric tissue as well as regulatory processes as silencing and epigenetic gene regulation are probable events. Apple trees are propagated vegetatively by grafting of scions onto rootstocks. Scions which have developed from nontransgenic or silenced cells can be used for propagation unknowingly.

Different studies on transgenic trees have described that the transgenic trait was less stable than originally thought (Höenicka and Fladung, 2006). The expression of the transgenes was either silenced at the transcriptional or the post-transcriptional level. Silencing was often found in transgenic lines with methylated transgene sequences. Methylation of the promoter sequence which drives the transgene lead to transcriptional gene silencing (TGS). Thereby the TGS could be mediated by surrounding heterochromatin, by endogenous repetitive sequences, by transgene-genomic junctions, by (trans)gene repeats, by aberrant promoter transcripts and by DNA viruses (summarized by Fagard and Vaucheret, 2000). Post-transcriptional gene silencing (PTGS) is a conserved surveillance mechanism of eukaryotes which defends host cells against viruses, protects the genome from transposons and regulates gene expression (Butaye et al. 2005). PTGS was often found in lines with methylation of the transcribed region of the transgene. PTGS could be induced by expression of sense, antisense and sense/antisense transgenes as well as by DNA and ribonucleic acid (RNA) viruses (Fagard and Vaucheret, 2000).

To study the uniformity and stability of transfer DNA (T-DNA) integration and gene expression level in transgenic plants, apple lines carrying the attacin $\mathrm{E}$ (attE) gene from Hyalophora cecropia, the $\beta$ glucuronidase (gusA) gene, and the neomycin phosphotransferase II (nptII) gene were used. Plants of these lines were investigated on transgene integration and expression as well as on the presence of transgene repeats and truncated T-DNA's, which can have an impact on the expression immediately after selection. Subsequent these plants were propagated in vitro on medium without aminoglycoside antibiotics to provide cells without nptII expression the opportunity to grow. After four 


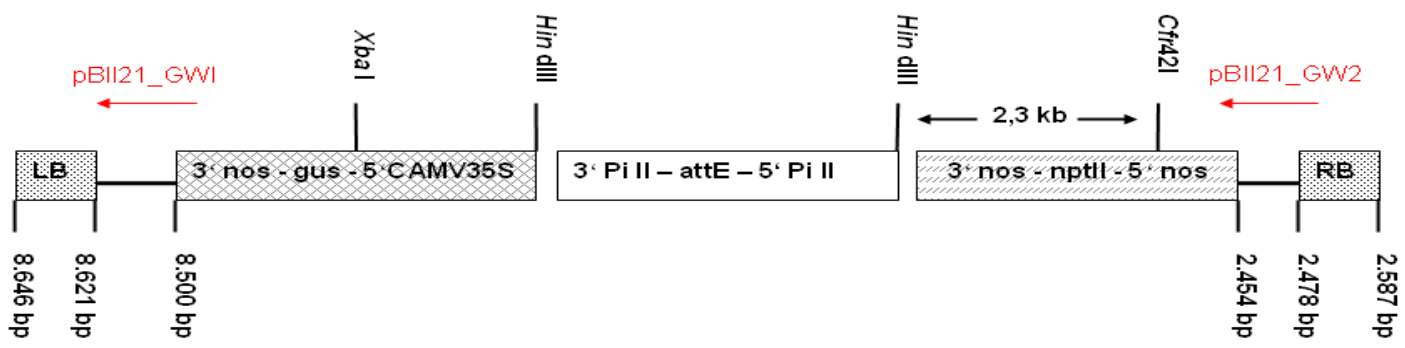

\begin{abstract}
Figure 1. T-DNA of the vector plasmid pLDB15. The vector backbone and the T-DNA of the plasmid pLDB15 are based on the binary vector pBI121. All UTR regions are labeled as 5' and 3'. nos: nos promoter/terminator; CaMV35S: cauliflower mosaic virus 35S promoter; Pill: promoter/terminator of proteinase-inhibitor II gene of Solanum tuberrosum; gus: $\beta$-glucuronidase gene; attE: attacin E gene of Hyalophora cecropia; nptll: neomycin phosphotransferase II gene. Approximate positions of restriction sites and primers used for PCR analysis: pBI121_GW1 and pBI121_GW2 for genome walking.
\end{abstract}

years under non-selective in vitro conditions we investigated the transgene integration and expression pattern in transgenic lines in comparison with data obtained at the beginning of their generation.

\section{MATERIALS AND METHODS}

\section{Plant material and transformation}

For plant transformation proliferating axillary shoot cultures of the apple scion cultivar 'Pinova' (Malus $x$ domestica BORKH) were used. The plant material was propagated and transformed using the EHA105 Agrobacterium tumefaciens strain and the vector plasmid pLDB15 (Figure 1) as described by Flachowsky et al. (2007). Regeneration and selection of transformed shoots were performed on medium containing $350 \mathrm{mg} \mathrm{l}^{-1}$ cefotaxime and $100 \mathrm{mg} \mathrm{l}^{-1}$ kanamycin. Regenerated meristems were excised 8 to 12 weeks after inoculation and independent transgenic lines from a single transformation event were obtained. Transgenic shoots were subcultured on the shoot proliferation medium with a selective agent. Kanamycin (100 mg l-1 $)$ was used until the meristem was established as a proliferating shoot, and was then replaced by paromomycin $\left(100 \mathrm{mg} \mathrm{l}^{-1}\right)$.

The presence of the transgenes was confirmed by PCR and RT-PCR analysis, Southern blot and ELISA assay for neomycin phosphotransferase II protein (NPTII). After four to six generations on medium containing paromomycin, the plants were grown on a MS propagation medium without a selective agent for about 50 generations (one generation corresponds to four weeks). Ten shoots of each line were selected and young leaves of each shoot were collected, frozen in liquid nitrogen and stored at $-80^{\circ} \mathrm{C}$.

\section{Polymerase chain reaction}

DNA extraction and PCR evaluation were done in a $25 \mu \mathrm{l}$ total reaction volume comprising 50 ng of genomic plant DNA, RNA or first strand copy DNA (cDNA) as described by Flachowsky et al. (2007). The specific forward (F) and reverse (R) PCR primers were as follows: for the nptII gene- nptII_F 5'-ACA AGA TGG ATT GCA CGC AGG3', nptII_R 5'-AAC TCG TCA AGA AGG CGA TAG-3'; for the attE gene- attE_F 5'-AGA TTG GTG CAT CTG CGA G-3', attE_R 5'-CCG AAG TTA GGC TCC CAA GA-3'; for the gusA gene- GUS_F 5'-GTG GAA TTG ATC AGC GTT GG-3', GUS_R 5’-GCA CCG AAG TTC ATG CCA GT-3'. The reaction conditions were as follows: denaturation at $94^{\circ} \mathrm{C}$ for $5 \mathrm{~min}$, then 30 cycles $-94^{\circ} \mathrm{C}, 1 \mathrm{~min}$ denaturation; $55-60^{\circ} \mathrm{C} 30 \mathrm{sec}\left(55^{\circ} \mathrm{C}\right.$ for attE, $60^{\circ} \mathrm{C}$ for gusA, $58^{\circ} \mathrm{C}$ for nptII) annealing and $72^{\circ} \mathrm{C}, 1-4$ min extension. After a final extension at $72^{\circ} \mathrm{C}$ for 5 min the amplified fragments were separated on a 0.8 - 1\% agarose gel. The quality of the genomic DNA used for this study was tested using primers specific for the endogenous apple gene $\mathrm{Mal}$ d3 (Mal d3_F: 5'-ATT GGC TAC GTG AGG AGT GG-3' and Mal d3_R: 5'-GGT GGA GGT GCT GAT CTT GTA G-3') and for 18S rDNA (18S_F: 5'-CTC GTA GTT GGA CCT TGG-3' and 18S_R: 5'-CTA ATG TAT TCA GAG CGT AGG-3'). These primers were designed based on the sequence files MDO277164 and AY374225 for Mal d3 and DQ341382 for 18S rDNA of the National Centre for Biotechnology Information (NCBI) database (http://www.ncbi.nlm.nih.gov/).

Total RNA extraction and reverse transcription were performed as described by Flachowsky et al. (2007). For the detection of expressed transgenes the same primers and conditions were used as described above. A PCR procedure for the endogenous apple housekeeping gene encoding for the elongation factor 1 alpha (EF1") was also performed to control the success of cDNA synthesis using the following primers: EF_F 5'-ATT GTG GTC ATT GGY CAY GT-3' and EF_R 5'-CCA ATC TTG TAV ACA TCC TG-3'.

\section{Quantitative RT-PCR}

Quantitative Real-Time PCR was performed as described by Flachowsky et al. (2007). For the detection of expressed transgenes nptII and gusA the primers nptII_RT1 5'-aga 
Table 1. Transgenic 'Pinova' apple lines: $n p t I I$ and gus $A$ activities in leaf tissue.

\begin{tabular}{|c|c|c|c|c|c|c|c|c|c|c|}
\hline \multirow{2}{*}{ Genotype } & \multicolumn{2}{|c|}{ nptII activity ${ }^{1}$} & \multicolumn{8}{|c|}{ gus $A$ activity ${ }^{4,5}$ of leaf } \\
\hline & First & Second & 1 & 2 & 3 & 45 & 6 & 7 & \begin{tabular}{l|l}
8 & 9
\end{tabular} & \begin{tabular}{l|l}
9 & 10
\end{tabular} \\
\hline T311 & $47 \pm 4.0$ & $3 \pm 0.2$ & 1 & 3 & 2 & 32 & 21 & 12 & 2 & \begin{tabular}{l|l}
2 & 4
\end{tabular} \\
\hline T315 & $24 \pm 0.9$ & $17 \pm 0.9$ & 2 & 1 & 2 & $2 \mid 2$ & 2 & $2 \mid$ & \begin{tabular}{l|l}
2 & 2
\end{tabular} & \begin{tabular}{l|l}
2 & 2
\end{tabular} \\
\hline T316 & $29 \pm 0.3$ & $14 \pm 0.3$ & 2 & 2 & 1 & $1 \mid 1$ & 1 & $|1|$ & 11 & $1 \quad 1$ \\
\hline T320 & $1 \pm 0.0$ & $7 \pm 0.4$ & 2 & 1 & 1 & $2 \mid 1$ & 2 & $2 \mid$ & 12 & \begin{tabular}{l|l}
2 & 1
\end{tabular} \\
\hline T321 & $7 \pm 0.2$ & $17 \pm 0.5$ & 5 & 5 & 5 & 55 & 5 & 5 & 5 & $5 \quad 5$ \\
\hline T322 & $62 \pm 5.0$ & $120 \pm 8.3$ & 4 & 4 & 4 & 33 & 3 & 4 & 33 & \begin{tabular}{l|l}
3 & 4
\end{tabular} \\
\hline T324 & $31 \pm 3.4$ & $61 \pm 13.6$ & 3 & 3 & 3 & 43 & 33 & 4 & 5 & $\begin{array}{ll}3 & 3 \\
\end{array}$ \\
\hline T328 & $28 \pm 1.1$ & $10 \pm 0.3$ & 2 & 2 & 1 & 22 & 2 & 2 & \begin{tabular}{l|l}
2 & 1
\end{tabular} & 2 \\
\hline T329 & $30 \pm 0.7$ & $35 \pm 2.0$ & 3 & 5 & 2 & 55 & 55 & 4 & $\begin{array}{lll}5 & 4\end{array}$ & \begin{tabular}{l|l}
4 & 4
\end{tabular} \\
\hline T333 & $30 \pm 1.1$ & $92 \pm 7.3$ & 4 & 4 & 5 & 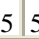 & 5 & $4 \mid$ & \begin{tabular}{l|l}
4 & 4
\end{tabular} & \begin{tabular}{l|l}
4 & 4
\end{tabular} \\
\hline T334 & $49 \pm 4.4$ & $31 \pm 2.2$ & 4 & 4 & 4 & 44 & $4 \quad 4$ & 4 & \begin{tabular}{l|l}
4 & 4
\end{tabular} & \begin{tabular}{l|l}
4 & 4 \\
\end{tabular} \\
\hline T335 & $22 \pm 1.7$ & $21 \pm 2.3$ & 2 & 1 & 4 & $4 \mid 2$ & \begin{tabular}{l|l}
2 & 1
\end{tabular} & $2 \mid 2$ & $2 \mid 2$ & 2 \\
\hline T336 & $18 \pm 0.9$ & $5 \pm 0.2$ & 4 & 4 & 4 & $4 \mid 4$ & $4 \mid 4$ & 2 & $2 \mid 4$ & \begin{tabular}{l|l}
4 & 5
\end{tabular} \\
\hline T338 & $26 \pm 1.1$ & $16 \pm 0.2$ & 2 & 4 & 2 & $2 \longdiv { 2 }$ & 24 & 4 & \begin{tabular}{l|l}
4 & 4
\end{tabular} & \begin{tabular}{l|l}
4 & 4
\end{tabular} \\
\hline Т340 & $27 \pm 3.4$ & $19 \pm 1.7$ & 4 & 4 & 5 & $4 \mid 4$ & $4 \mid 4$ & 4 & \begin{tabular}{l|l}
4 & 4
\end{tabular} & \begin{tabular}{l|l}
4 & 4
\end{tabular} \\
\hline T344 & $24 \pm 4.4$ & $11 \pm 0.9$ & 4 & 4 & 4 & $1 \mid 1$ & 14 & 4 & $1 \mid 1$ & 13 \\
\hline T345 & $13 \pm 3.0$ & $20 \pm 2.2$ & 1 & 1 & 2 & 23 & \begin{tabular}{l|l}
3 & 1
\end{tabular} & 2 & 33 & \begin{tabular}{l|l}
3 & 2 \\
\end{tabular} \\
\hline T347 & $50 \pm 1.5$ & $37 \pm 2.1$ & 4 & 4 & 1 & $4 \mid 4$ & $4 \mid 4$ & 3 & $1 \mid 1$ & $1 \quad 2$ \\
\hline T349 & $36 \pm 0.4$ & $20 \pm 1.1$ & 1 & 1 & 1 & $1 \mid 2$ & $2 \mid 1$ & $4 \mid$ & $1 \mid 1$ & $1 \mid 1$ \\
\hline T353 & $12 \pm 0.4$ & $46 \pm 2.2$ & 2 & 2 & 2 & 22 & 21 & 1 & 2 & 2 \\
\hline T355 & $2 \pm 0.1$ & $54 \pm 0.9$ & 1 & 1 & 1 & 11 & $1 \quad 1$ & 1 & $1 \mid 1$ & \begin{tabular}{l|l}
1 & 1 \\
\end{tabular} \\
\hline T357 & $2 \pm 0.0$ & $1 \pm 0.0$ & 3 & 3 & 3 & 33 & \begin{tabular}{l|l}
3 & 4
\end{tabular} & 4 & \begin{tabular}{l|l}
4 & 4
\end{tabular} & \begin{tabular}{l|l}
4 & 4
\end{tabular} \\
\hline T358 & $2 \pm 0.1$ & $18 \pm 0.6$ & 2 & 1 & 2 & $1 \mid 2$ & 2 & $|1|$ & $1 \mid 2$ & 1 \\
\hline T359 & $14 \pm 2.8$ & $54 \pm 1.0$ & 2 & 2 & 2 & 24 & $4 \quad 4$ & 2 & \begin{tabular}{l|l}
4 & 4
\end{tabular} & \begin{tabular}{l|l}
4 & 2
\end{tabular} \\
\hline T360 & $9 \pm 0.5$ & $38 \pm 2.1$ & 2 & 1 & 1 & $1 \mid 2$ & 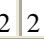 & 12 & \begin{tabular}{l|l}
2 & 1
\end{tabular} & 12 \\
\hline Т361 & $5 \pm 0.1$ & $1 \pm 0.0$ & 5 & 5 & 5 & 55 & $5 \quad 5$ & 5 & 5 & $5 \quad 5$ \\
\hline Pinova $^{6}$ & $0.7 \pm 0.0$ & $0.6 \pm 0.0$ & 5 & 5 & 5 & 55 & 55 & 5 & 5 & $5 \quad 5$ \\
\hline $\begin{array}{l}\text { 1NPTII prote } \\
\text { measureme } \\
\text { 2First evalua } \\
\text { selective ant } \\
\text { years of sub } \\
4 \text { Class of st } \\
\text { completely } \\
\text { blue, partiall } \\
\text { major part ( } \\
5 \text { The GUS a } \\
\text { medium with } \\
6 \text { Non-transf }\end{array}$ & $\begin{array}{l}\text { was perform } \\
\text { cs. } 3 \text { Second } \\
\text { re on mediut } \\
\text { pattern for } \\
\text { lue or blue } \\
\text { all white spo } \\
\text { \%) is white, } \\
\text { was perforn } \\
\text { elective age } \\
\text { d 'Pinova'. }\end{array}$ & $\begin{array}{l}\text { At selective ag } \\
\text { idual leaves i } \\
\text {; class 2: the } \\
3 \text { : tissue com } \\
\text { small blue sp } \\
\text { ransgenic line }\end{array}$ & & & & $\begin{array}{l}\text { nic li } \\
30 \%) \\
\text { le co } \\
\text { sue } \\
\text { rs of }\end{array}$ & & $\begin{array}{l}\text { ctivity } \\
\text { ium c } \\
\text { s afte } \\
\text { Class } \\
\text { the tis } \\
\text { ed; cl } \\
\text { pletel } \\
\text { cultur }\end{array}$ & $\begin{array}{l}\text { conta } \\
\text { er fou } \\
\text { s 1: ti } \\
\text { ssue } \\
\text { lass } \\
\text { ly wh } \\
\text { ure on }\end{array}$ & $\begin{array}{l}\text { aining } \\
\text { ur } \\
\text { tissue } \\
\text { e is } \\
4 \text { : the } \\
\text { hite. } \\
\text { n }\end{array}$ \\
\hline
\end{tabular}

ggc tat tcg gct atg-3', nptII_RT2 5-aag gtg aga tga cag gag3, gusA_RT1 5'-GTT CTG CGA CGC TCA CAC CGA TAC C-3' and gusA_RT2 5'-TCA CCG AAG TTC ATG CCA GTC CAG-3' were used. For attE the same primers were used as described before. The PCR conditions were as follows: denaturation for $3 \mathrm{~min}$ at $94^{\circ} \mathrm{C}$ followed by 40 cycles with $1 \mathrm{~min}$ denaturation at $94^{\circ} \mathrm{C}, 1 \mathrm{~min}$ annealing at $56^{\circ} \mathrm{C}$ to $65^{\circ} \mathrm{C}$ (depending on the primers) and $1 \mathrm{~min}$ elongation at $72^{\circ} \mathrm{C}$. Gene specific amplification was evaluated by melt curve analysis and agarose gel electrophoresis. To determine the amplification efficiencies, $15 \mathrm{ng}, 30 \mathrm{ng}, 60 \mathrm{ng}$ and $120 \mathrm{ng}$ cDNA of the transgenic line T311 were analyzed. The amplification efficiency and the calculation of the expression level were estimated as described by Flachowsky et al. (2007). All samples were normalized using the ribulose-1,5bisphosphate carboxylase/oxygenase activase mRNA (Ru_RT1 5'-gct tgt cca aga gca aga gaa t-3' and Ru_RT2 5'-ctc cct ccc ctc aat tat aac c-3') as an internal control sample. The mRNA expression levels measured after selection were set to be 1 . The mRNA transcript levels obtained after four years of subculture were rescaled relative to 1 .

\section{Southern blot analysis}

$10 \mu \mathrm{g}$ DNA was first digested with 100 units of HindIII and then with $\mathrm{XbaI}$ at $37^{\circ} \mathrm{C}$ (MBI Fermentas, St. Leon Roth, Germany) overnight. The restricted DNA was separated on a $0.8 \%$ agarose gel at $25 \mathrm{~V}$ overnight and transferred onto a nylon membrane (Roche Diagnostics, Mannheim, Germany). PCR amplified, ECF-labeled probes from the coding region of the attE gene (171 bp) and nptII marker gene (780 bp) were used for hybridization. The probes were amplified using the primers nptII_F and nptII_R for nptII and attE_F and attE_R for attE (see above). Hybridization and detection was performed using the ECF-Random-PrimeLabeling and Detection Kit (Amersham Biosciences, Freiburg, Germany) according to the manufacturer's manual.

\section{Methylation assay}

To assay the methylation of the nos promoter site, a double restriction of genomic DNA was performed as described by Ulian et al. (1996) with minor modifications. $10 \mu \mathrm{g}$ DNA was restricted with 100 units HindIII and 100 units Cfr42I (MBI Fermentas, St. Leon Roth, Germany). HindIII cleaves AAGCTT sequences. No sensitivity to $\mathrm{CpG}$ and $\mathrm{CpNG}$ sequences is known (http://www.fermentas.com). Cfr42I an isochizomer of SacII and SstII cleaves CCGCGG sequences, but only if the internal $\mathrm{C}$ is unmethylated. Methylated DNA would only be restricted with HindIII and after hybridization with a nos promoter specific probe a fragment of more than $2.5 \mathrm{~kb}$ is expected. Unmethylated DNA would be restricted with HindIII and Cfr42I with an expected fragment size of $2.3 \mathrm{~kb}$. The nos promoter probe was amplified using the primers nos_F 5'-CAC TGA TAG TTT AAA CTG AAG GCG G-3' and nos_R 5'-ACT ATT CGG CTA TGA CTG GGA ACA A-3’.

\section{Genome walking}

DNA adjacent to the T-DNA border sequences was obtained by anchor PCRusing the Genome Walker Kit (Clontech, Palo Alto, CA). $5 \mu \mathrm{g}$ of genomic DNA were restricted with DraI, EcoRV, ScaI, SmaI and SspI, respectively and used for ligation of the GenomeWalker adaptors. PCRs with the internal primers pBI121_GW1 (5'- 
Table 2. Number of T-DNA copies in 26 transgenic apple lines.

\begin{tabular}{|c|c|c|c|c|c|c|c|}
\hline \multirow{3}{*}{ Line } & \multicolumn{4}{|c|}{ Detected T-DNA fragments } & \multirow{3}{*}{$\begin{array}{l}\text { Copy } \\
\text { number }\end{array}$} & \multirow{3}{*}{ Loci } & \multirow{3}{*}{$\begin{array}{c}\text { Presence of truncated } \\
\text { T-DNA's and } \\
\text { transgene repeats }\end{array}$} \\
\hline & \multicolumn{2}{|c|}{ HindIII } & \multicolumn{2}{|c|}{ Xbal } & & & \\
\hline & nptII & attE & nptII & attE & & & \\
\hline T311 & 1 & 1 & 2 & 3 & 3 & 1 & $\begin{array}{l}\text { truncated copies }{ }^{3}, \\
\text { transgene repeat }\end{array}$ \\
\hline T315 & 8 & 2 & 8 & 6 & 8 & 8 & truncated copies ${ }^{2,3}$ \\
\hline T316 & 1 & 1 & 1 & 1 & 1 & 1 & \\
\hline T320 & 2 & 1 & 2 & 2 & 2 & 2 & \\
\hline T321 & 1 & 1 & 1 & 1 & 1 & 1 & \\
\hline T322 & 3 & 1 & 3 & 3 & 3 & 3 & \\
\hline T324 & 3 & 2 & 3 & 3 & 3 & 3 & truncated copies $^{2}$ \\
\hline T328 & 6 & 1 & 6 & 3 & 6 & 6 & truncated copies ${ }^{3}$ \\
\hline T329 & 4 & 1 & 4 & 3 & 4 & 4 & truncated copies $^{3}$ \\
\hline T333 & 2 & 1 & 4 & 3 & 4 & 2 & $\begin{array}{l}\text { truncated copies }{ }^{3}, \\
\text { transgene repeats }\end{array}$ \\
\hline T334 & 3 & 1 & 2 & 2 & 3 & 2 & transgene repeat \\
\hline T335 & 2 & 1 & 1 & 0 & 2 & 1 & $\begin{array}{l}\text { truncated copies }{ }^{3} \text {, } \\
\text { transgene repeat }\end{array}$ \\
\hline T336 & 2 & 1 & 2 & 1 & 2 & 2 & truncated copies ${ }^{3}$ \\
\hline T338 & 3 & 1 & 3 & 3 & 3 & 3 & \\
\hline T340 & 2 & 1 & 2 & 1 & 2 & 2 & truncated copies $^{3}$ \\
\hline T344 & 1 & 1 & n.a. & n.a. & $1^{1}$ & $1^{1}$ & \\
\hline T345 & 2 & 2 & n.a. & n.a. & $2^{1}$ & $2^{1}$ & truncated copies $^{2}$ \\
\hline T347 & 1 & 2 & n.a. & n.a. & $2^{1}$ & $2^{1}$ & truncated copies $^{2}$ \\
\hline T349 & 2 & 1 & 2 & 2 & 2 & 2 & \\
\hline T353 & 7 & 3 & 5 & 5 & 7 & 5 & $\begin{array}{l}\text { truncated copies }{ }^{2}, \\
\text { transgene repeats }\end{array}$ \\
\hline T355 & 2 & 2 & 2 & 2 & 2 & 2 & truncated copies ${ }^{2}$ \\
\hline T357 & 1 & 1 & n.a. & n.a. & $1^{1}$ & $1^{1}$ & \\
\hline T358 & 3 & 1 & 3 & 2 & 3 & 3 & truncated copies $^{3}$ \\
\hline T359 & 1 & 1 & 3 & 3 & $?$ & 1 & transgene repeat \\
\hline T360 & 1 & 1 & 2 & 2 & $?$ & 1 & transgene repeat \\
\hline T361 & 1 & 1 & n.a. & n.a. & $1^{1}$ & $1^{1}$ & \\
\hline Pinova $^{6}$ & 0 & 0 & 0 & 0 & 0 & 0 & \\
\hline
\end{tabular}

Results are based on one Southern experiment - the number of copies is possibly higher.

${ }^{2}$ Truncated copies assumed after detection of multiple attE signals on Hindlll digested DNA.

${ }^{3}$ Truncated copies assumed after detection of different numbers of $n p t / l$ and attE signals on Xbal digested DNA.

on-transformed 'Pinova'.

?: Results are ambiguous.

n.a.: not analysed. 
CTC TCA GGG CCA GGC GGT GAA G-3') and pBI121_GW2 (5'-GTA AAA CGG CTT GTC CCG CGT CAT C-3') in combination with the GenomeWalker adapter primer AP1 and a 10x diluted restriction-ligationmix were performed to amplify the left and right border adjacent regions. Nested PCRs were performed using the same internal primers, the adapter primerAP2 and a 100x diluted amplification product ofthe first PCR. Amplified products were separated on a $1 \%$ agarose gel. Fragments were isolated and ligated into the vector PCR 2.1-TOPO (TOPO TA Cloning ${ }^{\circledR}$-Kit, Invitrogen, Groningen) and transferred into One Shot ${ }^{\mathrm{TM}}$ cells according to the manual.

\section{Enzyme assays}

Two to three young leaves (20 mg leaf tissue) derived from different shoots of the same transgenic line were used to determine the amount of NPTII protein using a standard sandwich ELISA according to manufacturer's recommended procedure (5 Prime $\rightarrow 3$ Prime Inc., Boulder, $\mathrm{CO})$.

Histochemical GUS assay for detection of $\beta$-glucuronidase expression was performed on young leaves of 20 days old in vitro plants. The leaves were randomly selected from shoots of a transgenic line and placed in 12-well plates containing X-Gluc solution consisting of $100 \mathrm{mM}$ sodium phosphate $\mathrm{pH}$ 7.0, $0.5 \mathrm{mM}$ potassium ferricyanide, $0.5 \mathrm{mM}$ potassium ferrocyanide, and $0.1 \% \mathrm{w} / \mathrm{v}$ X-Gluc (MBI Fermentas, St. Leon Roth, Germany). After vacuum infiltration for $30 \mathrm{~min}$ the plates were incubated over night at $37^{\circ} \mathrm{C}$. The chlorophyll was removed with $5 \mathrm{ml}$ ethanol plus acetic acid (3:1) for 16 hrs at room temperature. Five general classes of GUS expression pattern in leaves were indicated: class 1 - tissue completely dark blue or blue coloured; class 2 - the major part (70-80\%) of the tissue is blue, partially small white spots; class 3 - tissue completely light blue coloured; class 4 - the major part (70-80\%) is white, partially small blue spots; class 5 - tissue completely white.

\section{RESULTS}

\section{Transgene integration and expression after selection on medium containing selective antibiotics}

We regenerated independent putative transgenic apple shoots of the cV 'Pinova' transformed with the attE, the nptII and the gusA genes. Putative transgenic shoots were selected on medium containing selective antibiotics (kanamycin and paromomycin) as described. Three young leaves of each selected shoot were used to isolate genomic DNA. This DNA sample was analyzed at the molecular level by PCR to confirm the presence of the attE or the nptII genes during the first generation. A total of 26 independent transgenic shoots, with detectable fragments for both genes were found. These shoots were propagated in vitro on medium containing cefotaxime and paromomycin to generate 26 different transgenic apple lines.

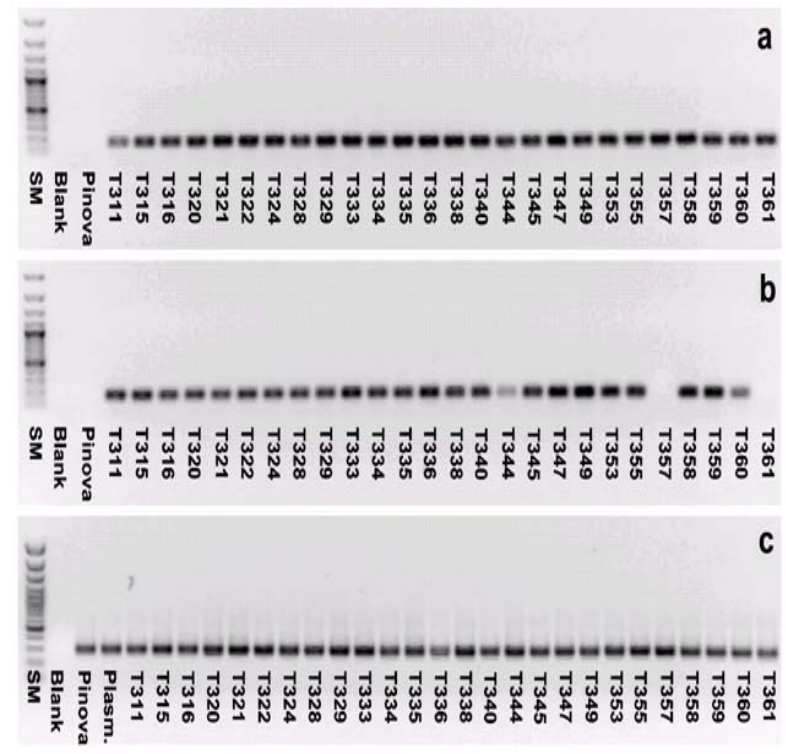

Figure 2. Evaluation of attE gene transcription in transgenic apple lines by RT-PCR. The transcription of attE was evaluated directly after regeneration (a) and after four years of subculture on medium without antibiotics (b). The quality of the cDNA isolated from T-lines after four years of subculture was checked by RT-PCR using primers specific to Mal $d 3$ (c). SM - molecular size marker 100 bp (MBI Fermentas); Plasm. - plasmid DNA.

The transcript levels of the attE and the nptII genes of each line were verified by RT-PCR technique (an example is given in Figure 2). All investigated lines showed fragments of the expected sizes for both genes. The translation of the nptII gene was evaluated by ELISA assay as described (Table 1). ELISA results indicated that all lines tested expressed the NPTII protein, except for the control cultivar 'Pinova' (as expected) and for line T320. Seven lines with a very low level of NPTII protein were detected (less than 10 $\mathrm{pg} / \mathrm{mg}$ leaf tissue). Fifteen lines showed high expression levels with more than $20 \mathrm{pg}$ NPTII protein/mg leaf tissue.

\section{Evaluation of transgenic lines after four years of subculture on medium without antibiotics}

Following the first molecular evaluation, all 26 transgenic lines were propagated for a period of four years on medium without selective agents. During these 50 generations (one subculture is about four weeks) transgenic cells and cells without the transgenic trait (cells without the transgene and/or without transgene expression) were both enabled to grow. Subsequently, molecular evaluation of the material was repeated. Genomic DNA of three young leaves per line was isolated and verified for the presence of the nptII and attE genes by PCR as described. Supplementary, the presence of the gusA and Mal $d 3$ genes were verified. The Mal d3 gene, an endogenous apple allergen was used as internal control to check the quality of each DNA sample. 
As expected, this gene was present in all DNA samples investigated. Fragments of the appropriate size were detected for attE, nptII and gusA in 23 of 26 apple lines. In the DNA sample of line T347 no fragment for the gusA gene was obtained, whereas nptII, attE and Mal d3 were detectable. In the DNA samples of lines T357 and T361 the transgenes attE, nptII and gusA failed. All PCR reactions were repeated with identical results.

Total RNA of each line was isolated and reverse transcribed as described. All lines were investigated for the presence of nptII and attE transcripts. Fragments for both genes were detectable in 24 out of 26 lines. No fragments for nptII and attE were detectable in T357 and T361 (Figure 2).

The amount of NPTII protein was evaluated via ELISA assay and the obtained results indicated different NPTII protein levels in a range of apple lines compared to the results of the first evaluation (Table 1). For lines T357 and T361, as expected from the results obtained by PCR and RT-PCR, no significant NPTII protein expression was obtained. Overall, lower levels of NPTII protein was indicated in 12 lines (for example in line T311), whereas ten lines showed an increase in nptII expression (T355) over the time of four years. Only two lines (T329 and T335) had approximately the same level of protein expression.

The activity of the $\beta$-glucuronidase in leaf tissue was verified by a histochemical GUS assay based on the intensity of blue staining pattern. Figure 3 illustrates the staining pattern for individual leaves in which lines T349, T355 and T359 are used as example. Table 1 summarizes the results of the gusA activity for all lines tested. There was stable GUS activity in eight lines (T315, T316, T320, T328, T353, T355, T358, T360) in which all tested leaves were assigned to class 1 (tissue completely dark blue or blue colored) or class 2 (the major part of the tissue is blue with partially small white spots). For two lines (T321 and T361) no activity of the gusA gene was detected (class 5 tissue completely white). In line T321 an appropriate fragment for gusA was obtained by RT-PCR analysis, indicating that gusA transcripts were present. On several leaves of the lines T333, T334 and T340 only blue spots were found (class 4 - major part of the leaf is white with partially small blue spots). All other leaves of these lines were completely white (class 5 - white leaf uncoloured). In line T347, five leaves out of ten were assigned to class 4 . The remaining five leaves were blue coloured at a different degree (classes 1, 2 and 3). In this line a gusA gene specific fragment was detectable by RT-PCR, whereas the respective fragment failed in PCR analysis for gene integration. PCR and RT-PCR were done on DNA and cDNA obtained from different samples of leaf tissue.
Possibly line T347 is a chimera with cells containing correct T-DNA's and cells containing truncated copies without the gusA gene. The results obtained by the GUS assay support this hypothesis.

In summary, from the results of the gusA activity detected by histochemical staining of leaf tissue and the activity of the nptII gene detected by ELISA assay, it could not be asserted that lines with a high amount of NPTII protein showed also a high activity of the gus $A$ gene and vice versa.

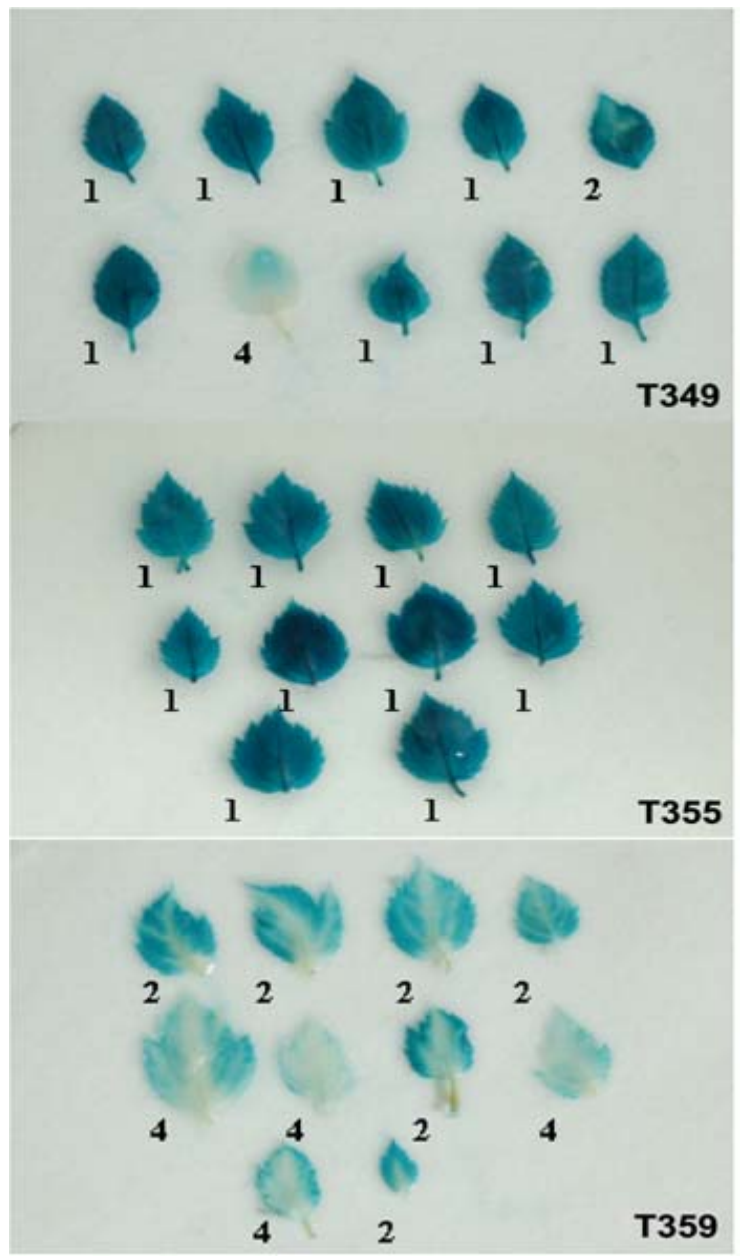

Figure 3. Histochemical detection of gus $A$ gene expression leaves of each transgenic line were randomly selected and usec classes of expression patterns were observed (class 1: tissue cc major part $(70-80 \%)$ of the tissue is blue, partially small white $s p$ class 4 : the major part $(70-80 \%)$ is white, partially small blue $\mathrm{spc}$

\section{Investigation on transgene integration}

All 26 transgenic lines were investigated on integration of two of three transgenes via Southern hybridization. About 20 to 30 young leaves (200 $\mathrm{mg}$ ) of each line were randomly collected and frozen in liquid nitrogen. The genomic DNA of these leaves was isolated, cleaved with HindIII and blotted onto nylon membranes as described. The membranes were then hybridized with attE-and nptII- 
specific ECF-labeled PCR probes. As expected from independent transformants, the hybridization patterns observed using the nptII probe were variable, reflecting the different sites of transgene integration and different transgene copy numbers (Table 2). Subsequently, the membranes were stripped and hybridized a second time with the attE probe. 20 lines showed a single fragment of the same size as expected because the attE gene is flanked by two HindIII sites (Figure 1). Surprisingly six lines with two or three fragments were found (Table 2). This fact suggests the integration of truncated T-DNA copies. A second Southern hybridization experiment using XbaI digested DNA was performed on 21 out of 26 lines to obtain additional information about the number as well as the configuration of integrated T-DNA copies. XbaI was used because this enzyme cuts only once within the T-DNA. The XbaI site is located between the CaMV $35 S$ promoter and the gusA gene. Due to this, identical hybridization patterns are expected by hybridization with nptII and attE specific probes, whereas different hybridization patterns would indicate the presence of truncated copies. The membranes were hybridized with probes specific to nptII and $a t t E$, and 12 lines with identical hybridization patterns were found (Table 2). Nine lines showed different pattern after hybridization with $n p t I I$ and attE probes. Single copy integration could only be assumed for at most five out of 26 lines. The remaining lines have two or more T-DNA copies.

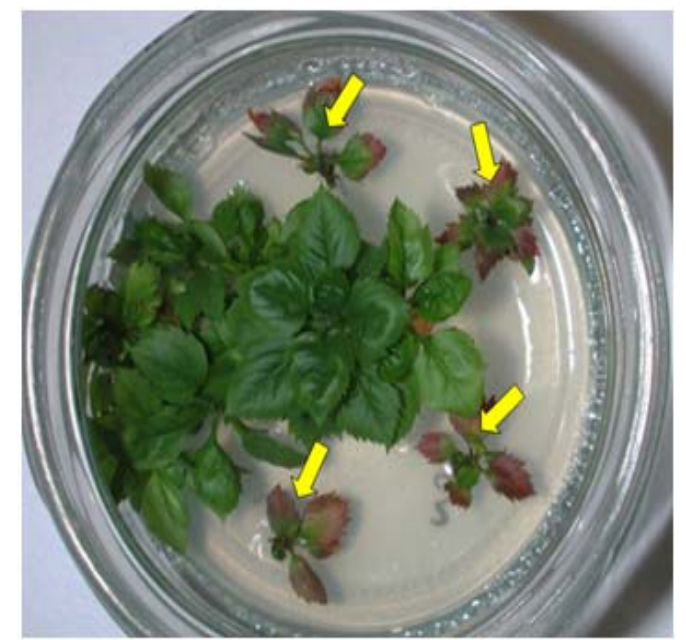

Figure 4. Individual shoots of the transgenic line T357 exposed on medium containing paromomycin after four years of subculture without selection pressure. Shoots which died on medium containing paromomycin are indicated by yellow arrows.

\section{nptIl expression of individual shoots and their subsequent evaluation}

After four years of plant propagation in vitro without selection pressure, ten representative shoots of each transgenic line were selected and dissected into two segments. One segment was placed on selection medium containing $100 \mathrm{mg} / \mathrm{l}$ paromomycin which is more effective than kanamycin. After six weeks of growth a morphological evaluation of these shoots was carried out. The other segment of the shoot was grown on medium without antibiotics and used for nucleic acid and protein detection. No visible morphological effects were found within plants of 23 transgenic lines when exposed to selection medium containing paromomycin as a selection agent. Almost all shoots grew normally showing green and vital leaves. Visible effects were found on shoots of three lines T311, T357 and T361. The shoots of line T311 had partially brown leaves and their growth was weak. Four shoots of line T357 died after six weeks (Figure 4), however, the remaining six shoots were green and vital. All shoots of line T361 turned brown and died. In order to study these three lines, the identical segment of each shoot which was grown on medium without antibiotics was used for molecular evaluation.

Molecular evaluation of T311 single shoots. The genomic DNA of each shoot was isolated and investigated on the presence and integration of the transferred genes by PCR and Southern hybridization. Both genes (nptII and attE) tested were present in the DNA sample of each of the ten T311 shoots as confirmed by PCR. Subsequently, the DNA was cleaved with HindIII and evaluated by Southern hybridization using $n p t I I$ as well as attE specific probes as described. The results obtained from this experiment were identical to the results obtained four years ago using DNA of plants growing on medium containing paromomycin (Table 2). Only one signal for each gene was detectable. However, based on a quantitative RT-PCR procedure it was found that the transcript levels of all three transgenes (nptII, gus $A$ and attE) were clearly reduced in comparison to the transcript levels obtained four years ago (Figure 5). Accordingly, the NPTII protein level was also quite low (Table 1). This and the fact that all 10 shoots had problems to grow on medium containing paromomycin indicated a down-regulation of the nptII marker gene expression. To understand this down-regulation, the nos promoter site was evaluated for DNA methylation. The DNA of each shoot was hybridized after double digestion with HindIII and Cfr42I using a nos promoter specific probe. All 10 shoots showed one fragment with a size of about $2.3 \mathrm{~kb}$ as expected for non-methylated DNA (data not shown). This indicates that the nos promoter was not methylated at the Cfr42I site.

Following the gusA histochemical staining procedure presented in Figure 6, only three of ten investigated leaves were fully stained dark blue (class 1 ). The other leaves of this line were completely light blue or, partially white or blue coloured (class 2, 3 and 4), respectively (Figure 6c). Within white coloured leaf segments sometimes a small number of blue coloured cells were found. These cells often were located around the leaf veins (Figure 6d). Two leaves of line T311 were selected. Both leaves contained blue and 
white coloured leaf segments. These leaves were used to isolate the genomic DNA of different coloured tissue (black framed areas in Figure 6c). The quality of all four DNA samples was checked by PCR with primers specific for endogenous apple 18S rDNA. A fragment with the expected size was amplified in each of the four DNA samples (Figure 6f). Subsequently the DNA was tested for the presence of the gusA and the nptII genes by PCR. Both genes were detectable in the blue coloured leaf segments (segments 3 and 4), however only in one (segment 1) of the white segment samples (Figure 6e). This indicated that the gusA gene is present but not expressed in white coloured cells of this leaf (segment 1). In the sample with the white coloured petiole (segment 2) no transgene was detectable by PCR.

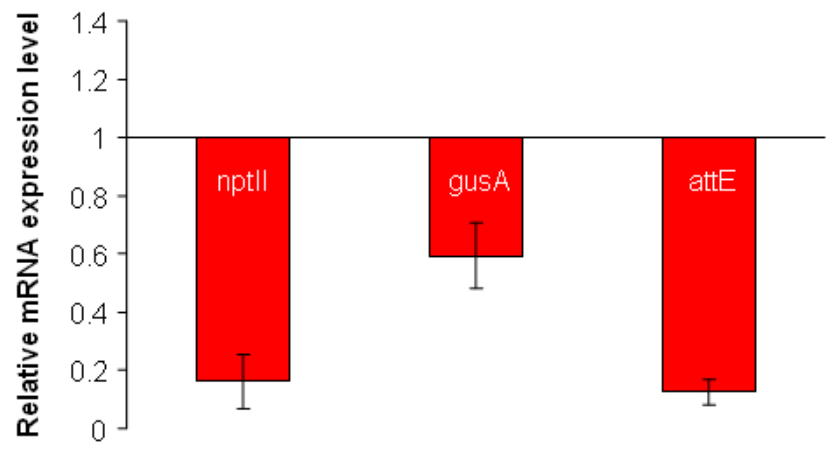

Genes investigated

Figure 5. Evaluation of transgene mRNA expression levels of line T311 after four years of subculture. The mRNA expression levels of each transgene were measured after the selection on medium containing antibiotics. These levels were set to be 1 . The expression levels obtained after four years of subculture were expressed in relation to 1 . Bars indicate the standard deviation.

Molecular evaluation of T357 single shoots. Six shoots out of ten from line T357 had a normal growth (Figure 4). DNA-fragments with the expected size of attE and nptII were amplified (Figure 7a and Figure 7b) by PCR. Single copies of each gene were indicted by Southern hybridization of HindIII restricted DNA (Data not shown). This is identical to the hybridization pattern obtained on HindIII restricted DNA of this line four years ago (Table 2). In the remaining four shoots no transgenes were detectable by PCR and Southern blot.

The T-DNA adjacent regions were isolated to explain the reason for the absence of the transgenes in four out of ten shoots. Genomic DNA was isolated from a shoot with stable integration and detectable transcript levels of each gene and used for a Genome Walker procedure. For the region adjacent to the right T-DNA border a $1.353 \mathrm{bp}$ fragment descendent from SmaI restricted DNA was isolated. This fragment showed a total sequence identity of $216 \mathrm{bp}$ to the right border adjacent T-DNA of pBI121 (position 2.479 to 2.587) without the right border. The T-DNA was truncated directly at the border followed by 1.208 bp of a flanking sequence. The fragment was terminated by the genome walker linker including the destroyed SmaI site. For the region adjacent to the left border, a 913 bp fragment isolated from DraI restricted DNA was obtained. This fragment contained 143 bp TDNA of the vector pBI121 (position 8.501 to 8.643) including 22 bp of the left border. Three bases (TGG) of the left border were remaining. The vector sequence was followed by 744 bp of a flanking sequence. This fragment was flanked by the genome walking linker including the destroyed DraI site.

Both sequences were combined to reproduce the genomic integration site of T-DNA into the genomic DNA of line T357. This sequence has a length of 1.952 bp with an AT content of $64 \%$. 97 bp of the right border adjacent region showed 88\% identity to the 5' untranslated region (UTR) of the Pyrus pyrifolia PPACS1 gene for ACC synthase (AB080677.1) between position $1.447 \mathrm{bp}$ and $1.543 \mathrm{bp}$. 91\% identity was found for 93 bp of the sequence flanking the left border. This showed a high level of similarity to the 3' UTR of the Malus domestica UDP glucose:flavonoid 3O-glucosyl transferase (AF117267) between position 1.671 bp and 1.763 bp. No significance was found for the prediction of ORF's and potential genes.

Specific primers for both borders of the integration site were designed to analyze genomic changes during T-DNA integration (Figure 8). These primers were used to study the original non-transgenic genotype 'Pinova', one shoot of line T357 with a T-DNA integration (T357_10) and one shoot without a T_DNA integration (T357_1) by longrange PCR. The original genotype 'Pinova' showed a fragment of 409 bp which was nearly identical to the sequence of the integration site of line T357. The PCRamplified fragment of 'Pinova' was 12 bp longer than expected (Figure 8). These twelve bases were directly located at the integration site. Probably, they were removed during T-DNA integration. The remaining sequence was identical. Four bases of the genomic integration site (CCTG) showed a micro-homology to the first four integrated bases of the T-DNA left border. No filler bases were found. A fragment identical to the genomic DNA of the $\mathrm{cv}$ 'Pinova' was obtained from the transgene containing shoot T357_10. This fragment is equal to the allelic sequence of the integration site. The amplification of a fragment with integrated T-DNA failed; probably this fragment is too long. Therefore, primers T357_F and T357_R were used in combination with the T-DNA specific primers pBI121_GW1 and pBI121_GW2 to evaluate all ten shoots of T357. Only in the six shoots, showing a normal growth on medium containing paromomycin and which showed a stable T-DNA integration, were fragments with the expected sizes amplified (Figure 7c and Figure 7d). For the remaining four shoots no fragments were detectable.

In the case of shoot T357_1, the PCR analysis using specific primers T357_F and T357_R resulted in one PCR product. The length of this product was equal to the size of the 
PCR product obtained from the non-transgenic cv 'Pinova'. The PCR product of T357_1 was ligated into the PCR 2.1-TOPO vector and the inserts of several clones were sequenced. All sequenced inserts were identical to the original non-transgenic 'Pinova' sequence. In each of the samples the twelve bases at the integration site were present. No deletions or residuals of T-DNA were detected.

The results for line T357 suggest a chimeric character of the tissue, as four shoots, which died after selection on an antibiotic containing medium, were obviously generated from non-transgenic cells.

Molecular evaluation of T361 single shoots. All ten shoots of line T361 died after six weeks on an antibiotic containing propagation medium. For this line one T-DNA copy of the transgenes was detected subsequent to the selection on medium containing paromomycin. After four years of subculture without selection pressure the transferred genes were unverifiable by PCR and Southern blot. The quality of the DNA used for PCR and Southern blot was good because a Mal d3 specific fragment could be amplified by PCR. The reason for the lack of the transgenes remains unclear and irreproducible at the moment. Possibly, this line was also a chimera and the transgenic cells were lost during four years of subculture without selection pressure. On the other hand the leakage of the transgenes could be also a result of an illegitimate recombination event.

\section{DISCUSSION}

In the presented study we have evaluated 26 transgenic apple lines transformed with the construct pLDB15 containing the genes nptII, attE as well as gusA. These lines were investigated on integration and expression of the transferred genes subsequent to propagation under selection pressure and after four years of in vitro culture on a nonselective propagation medium. The propagation of transgenic tissue on a non-selective medium was done to mimic the situation without selection pressure. These manmade conditions which are naturally present in the field were created to allow cells with and without the transgenic trait to grow. Climatic conditions such as irradiation and temperature cycling are known to have an effect on gene expression but were not considered in our study.

All 26 transgenic lines investigated after transformation showed correct integration of at least one copy of the transferred genes. Transcripts of nptII and attE were detectable, and all lines expressed the NPTII protein except for line T320. For this line a very low amount of NPTII protein was found which was equal to that obtained for the non-transgenic control. It is not evident at the moment why the level of NPTII expression was so low because four years later significantly more NPTII protein was found. The transgene expression was possibly effected by the transgene integration site, which may result in modulations of the temporal regulation of the transgene activity (van Leeuwen et al. 2001).

After four years of in vitro cultivation, the molecular studies were repeated on tissue samples of the identical 26 transgenic apple lines. In the DNA samples of lines T357 and T361 the transgene was no longer detectable by PCR. In addition, ten transgenic shoots of each line were placed on medium containing paromomycin. All lines investigated, except lines T311, T357 and T361, exhibited a normal growth on paromomycin which is evidence for stable expression of the NPTII protein. In shoots of line T361, the T-DNA was no longer detectable as shown previously by PCR results. Similar results were obtained in four shoots ofline T357. No T-DNA-residuals, deletions or genomic substitutions, which suggest the loss of inserted transgenes, were found in four shoots out of ten. However, six shoots showed a stable integration of one intact T-DNA copy. The results obtained in both lines argue more for a segregation of chimeric propagation material than for a physical loss of the transgene as a result of illegitimate recombination. The same conclusion is true for line T347. No gusA gene was detected in this line by PCR using DNA obtained from three individual leaves. The native gene $\mathrm{Mal} d 3$ and the transgenes nptII and attE were detectable within the same DNA sample. However, several blue coloured leaves indicated clearly the presence of gusA gene expression in other leaves of the same line. This line could be explained

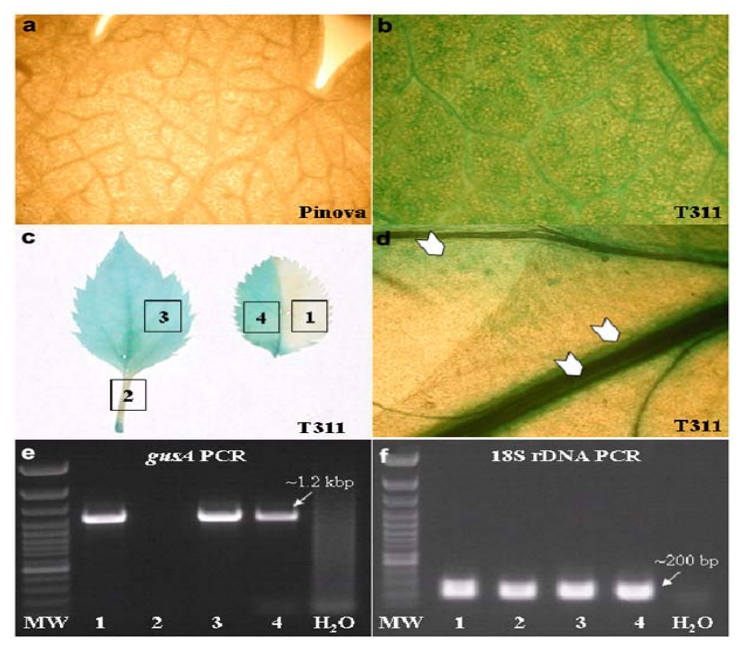

Figure 6. Histochemical detection of $\beta$-glucuronidase expression and molecular detection of the gus $A$ gene in individual leaves of the 'Pinova' transgenic line T311. Ten individual leaves of the line T311 were evaluated (see also Table 2). (a) Leaf segment (white colored) of the non-transgenic cultivar 'Pinova'. (b) Leaf segment of the transgenic line T311 (blue colored). Some leaves of this line were merely partial blue colored (c, d). White arrows represent blue stained tissue (d). Four different leaf segments (black framed in Figure 6c) were used to evaluate the presence of the transgenes by PCR (e). The designation of the samples in Figures $6 \mathrm{e}$ and $6 \mathrm{f}$ is equal to Figure 6c (MW - 100bp molecular weight marker, MBI Fermentas). The quality of the DNA was checked by PCR using $18 \mathrm{~S}$ rDNA specific primers (f). 
as a mixture of cells with complete T-DNA copies and cells with truncated T-DNA copies. The presence of both complete and truncated copies was also confirmed by Southern blot.

The regeneration of escapes and chimeric shoots that emerge during transgenesis is a major problem in most transformation systems (Caboni et al. 2000; Dominguez et al. 2004). For transformation systems based on the development of adventitious shoots directly from leaf tissue, as we have used in our study, the production of chimeric plants was described several times (Rugini et al. 1997; Matthews et al. 1998). It was shown by Schmülling and Schell (1993) that transgenic plants regenerated from leaf disks and grown on selective media have not necessarily the same clonal origin. This means, that the development of adventitious shoots does not necessarily lead to plants derived from single cells. The development of chimeras and escapes is furthermore possible by transient expression of the marker gene during early stages of the regeneration process (Park et al. 1998), in the presence of persistent Agrobacterium cells in infected leaf tissue (Birch, 1997) or as a follow of the protection of non-transgenic cells by the surrounding transformed cells (Birch, 1997; Park et al. 1998). The ineffectiveness of the antibiotic kanamycin as a selective agent by species with an endogenous tolerance could also result in the development of escapes (Costa et al. 2002). Differences in the response to the selection pressure among cultivars were also described for apple (Maximova et al. 1998). Based on our results it could be assumed that 'Pinova' is more tolerant to kanamycin and possibly induces a number of primordia with multicellular origins. However the number of chimeric plants is often higher than expected. In Citrus more than $12 \%$ chimeras were found after proliferation of gusApositive shoots (Dominguez et al. 2004). The development of chimeric plants depends mostly on the transformation system which is responsible for whether dedifferentiated or differentiated cells become transformed. The transformation of differentiated cells as described here has often resulted in periclinal chimeras (Fladung and Ahuja, 1997). In most cases with periclinal chimeras only one cell layer, the more accessible L1 is transgenic (Fladung and Ahuja, 1997). In angiosperms, the cells of the shoot apical meristem are normally organized into three different layers (Olbricht et al. 2006). Cells of the first layer (L1) form the epidermis of leaf organs. Cells of the second layer (L2) form mesophyll tissue in petals and leaves. Furthermore, vascular tissue may also originate from L2. Cells of the third layer (L3) form the inner mesophyll and vascular tissue of leaves and the adventitious roots (Poethig 1989). The absence of the T-DNA sequences in the four shoots of T357 as well as in line T361 argues against a periclinal chimera, because axillary meristems of periclinal chimeras (as used for the propagation of the transgenic lines) normally maintain the chimeric character (Tian and Marcotrigiano, 1993; Szymkowiak and Sussex, 1996). More probable is a segregation of sectorial chimeric tissue. In transgenic sectorial chimeras all cell layers were equally affected and the tissue of such plants is a mixture of transgenic and non-transgenic areas.

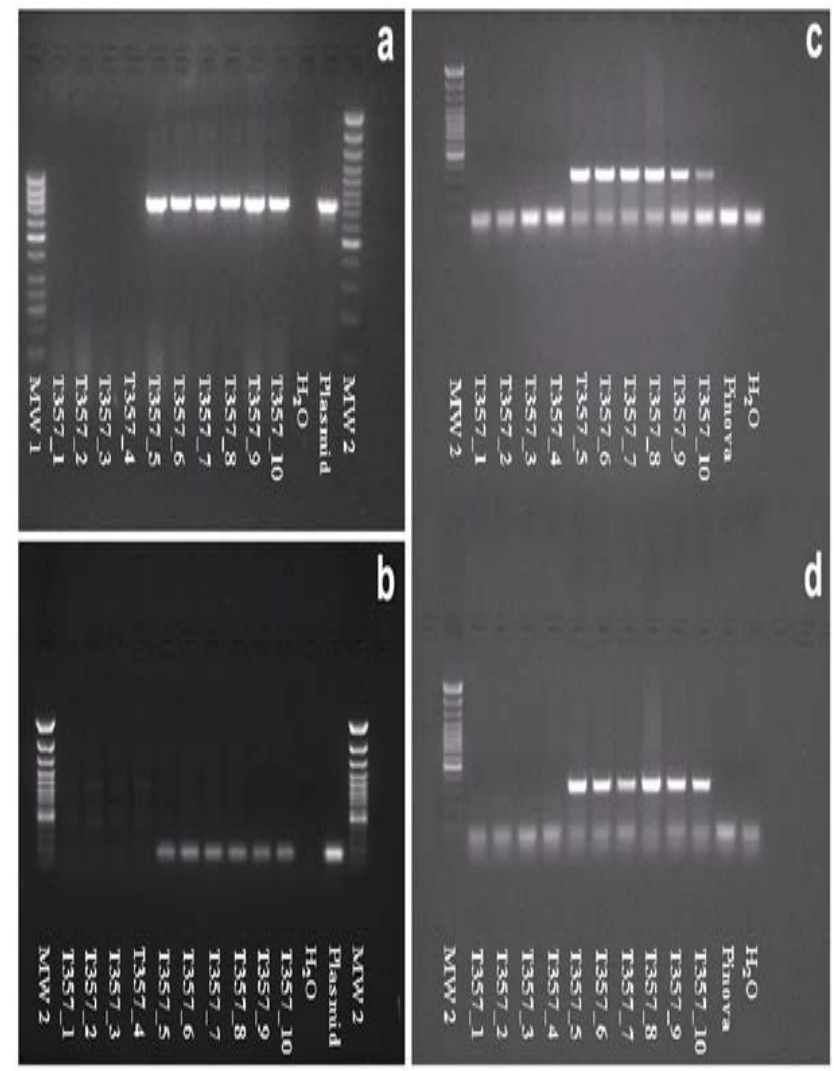

Figure 7. PCR analysis of single shoots of the 'Pinova' transgenic apple line T357. Genomic DNA was extracted from leaf tissue of ten individual shoots:

(a) Using nptll specific primers;

(b) Using attE specific primers;

(c) Using the T-DNA specific primer pBI121_GW2 and the primer T357_F to amplify the right border adjacent region;

(d) Using the T-DNA specific primer pBI121 GW1 and the primer T357_R to amplify the left border adjacent region. MW 1 - 50 bp molecular weight marker, MW 2 - 100 bp molecular weight marker (both MBI Fermentas).

Chimeric tissue was also detected in single leaves of line T311. For this line it was shown, that cells with normal gusA gene expression and cells without gusA gene expression are enabled to be present in the same plant tissue. Further, it was found that after four years of subculture on non-selective medium all three transferred genes (nptII, attE and gusA) were down-regulated at the transcriptional level. Previously, TGS was often found in lines containing inverted repeats (Mittelsten-Scheid et al. 1991). Therefore it was assumed that the presence of inverted repeats inevitably lead to gene silencing. Later on it was assumed by Muskens et al. (2000) that the potential of inverted repeats to produce dsRNA's might be the key of gene silencing. However, Lechtenberg et al. (2003) showed recently in transgenic Arabidopsis that lines containing inverted repeat T-DNA structures which are not transcribed are not prone to silencing. Similar results were obtained by Meza et al. (2002). The results of Meza et al. (2002) 


\author{
T357_F

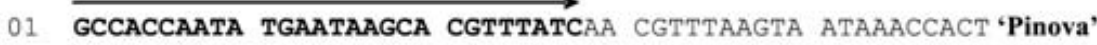 \\ 01 GCCACCAATA TGAATAAGCA CGTTTATCAA CGTTTAAGTA ATAAACCACT integration site of T357 \\ 51 CATTAACTTT CATGTCATTT AGTTTTCAAA ACTTTGTCTT TAAATTTAGT 'Pinova' \\ 51 CATTAACTTT CATGTCATTT AGTTTTCAAA ACTTTGTCTT TAAATTTAGT integration site of T357 \\ 101 CTTCCTAACA TTACCGTATT TTATAATGTT GACACAAAAA ATAACATAAA 'Pinova' \\ 101 CTTCCTAACA TTACCGTATT TTATAATGTT GACACAAAAA ATAACATAAA integration site of T357

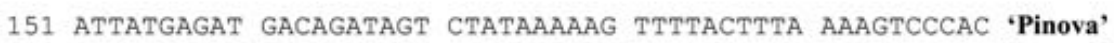 \\ 151 ATTATGAGAT GACAGATAGT CTATAAAAAG TTTTACTTTA AAAGTCCCAC integration site of T357
}

Figure 8. Comparison of the real sequence of the apple cv. 'Pinova' and the sequence of the genomic T-DNA integration site in line T357. The real sequence was amplified using sequence-specific primers T357_F and T357R (bold letters) for genomic DNA of the non-transgenic genotype 'Pinova'. The sequence of the integration site is based on information of the T-DNA flanking regions obtained after a Genome Walking procedure. Both sequences are nearly identical. Differences were found at the integration site (red coloured). A micro-homology was obtained between four bases of the genomic sequence and the first integrated bases of the T-DNA left border. Three bases (blue coloured) of the left border were truncated.

showed clearly that there is no correlation between the presence of inverted repeats and methylation, nor between silencing and methylation. Summarizing it was concluded that the occurrence of repeated T-DNA copies is not inevitably correlated with gene silencing and the loss of transgenic traits (Hoenicka and Fladung, 2006). On the contrary it was found that transcribed inverted repeats (Hamilton et al. 1998; Waterhouse et al. 1998) or doublestranded RNA containing promoter sequences (Mette et al. 2000; Yang et al. 2005) trigger silencing. Whether the presence of transgenic repeats and truncated T-DNA copies at the same locus are the reason for the TGS in line T311 is not definitely concluded. A further investigation on the presence of read-through transcripts will give a more detailed insight.

Differences in the level of NPTII protein expression were found between individual transgenic lines. In our case there was no correlation between the copy number and the level of gene expression. The correlation between copy number and transgene expression has been controversial for a long time. Several authors reported a positive correlation whereas other authors found no or negative correlation (see Schubert et al. 2004). Recently, detailed studies were carried out which showed that the presence of two or more transgene copies can promote an increase in the level of transgene activity (Schubert et al. 2004; Marenkova and Deineko, 2006). Down-regulation and silencing is expected if the copy number of the introduced genes exceeded a gene-specific threshold (Schubert et al. 2004). The reason for the occurrence of differences in NPTII expression in lines investigated in this study is not obvious because these lines are variable in their number of integrated T-DNA copies and truncated T-DNA's and transgenic repeats were additionally found.

The quantitative data for the NPTII protein measured immediately after selection on antibiotics and four years later were statistically analyzed. The differences found within individual lines were more affected by the genotype than by the time of cultivation. There were no significant differences in the NPTII protein expression level between 
both measurements. No correlation was found between the expression pattern of NPTII and GUS, although both genes were present in the same T-DNA. Similar results were described on transgenic rape (Melander et al. 2006).

\section{CONCLUDING REMARKS}

In the presented study, we have shown that while most of the molecular techniques can reliably detect the presence of transgenic cells, they often fail to detect mixtures of cells with and without the transgenic trait. Conclusions on the uniformity of the transgenic tissue as well as on expression are often masked as a consequence of non-transgenic and silenced cells neighbouring present in the tissue. The occurrence of chimeras is mostly depending on the transformation and selection system. Improved transformation methods as the use of axillary shoot meristems (Matsuda et al. 2005) or vegetative shoot apices (Caboni et al. 2000) could help to solve this problem. Furthermore we conclude that the selection of transgenic lines developed from a single transgenic cell is only possible after evaluation of multiple tissue samples of one and the same line. Different results within samples of the same line are a first indication for the presence of chimeric tissue.

\section{ACKNOWLEDGMENTS}

The authors acknowledge Prof. Dr. W.E. Weber of the Martin-Luther University Halle-Wittenberg (Germany) for his helpful and critical comments.

\section{REFERENCES}

BIRCH, Robert G. Plant transformation: Problems and strategies for practical application. Annual Review of Plant Physiology and Plant Molecular Biology, June 1997, vol. 48, p. 297-326.

BRIVIBA, K.; LEIN, K. and SZANKOWSKI, I. Analysis of gene expression stability in transgenic apple plants and apple fruit. Acta Horticulturae, December 2004, vol. 2, p. 457-462.

BUTAYE, Katleen M.J.; CAMMUE, Bruno P.A.; DELAURE, Stijn L. and DE BOLLE, Miguel F.C. Approaches to minimize variation of transgene expression in plants. Molecular Breeding, August 2005, vol. 16, no. 1, p. 79-91.

CABONI, E.; LAURI, P. and D’ANGELI, S. In vitro plant regeneration from callus of shoot apices in apple shoot culture. Plant Cell Reports, July 2000, vol. 19, no. 8, p. 755-760.

COSTA, M.G.C.; OTONI, W.C. and MOORE, G.A. An evaluation of factors affecting the efficiency of Agrobacterium-mediated transformation of Citrus paradisi (Macf.) and production of transgenic plants containing carotenoid biosynthetic genes. Plant Cell Reports, November 2002, vol. 21, no. 4, p. 365-373.
DOMINGUEZ, Antonio; CERVERA, Magdalena; PEREZ, Rosa M.; ROMERO, Juan; FAGOAGA, Carmen; CUBERO, Jaime; LOPEZ, Maria M.; JUAREZ, José A.; NAVARRO, Luis and PEÑA, Leandro. Characterisation of regenerants obtained under selective conditions after Agrobacterium-mediated transformation of citrus explants reveals production of silenced and chimeric plants at unexpected high frequencies. Molecular Breeding, September 2004, vol. 14, no. 2, p. 171-183.

FAGARD, M. and VAUCHERET, H. (Trans)gene silencing in plants: how many mechanisms? Annual Review of Plant Physiology and Plant Molecular Biology, June 2000, vol. 51, p. 167-194.

FLACHOWSKY, Henryk; PEIL, Andreas; SOPANEN, Tuomas; ELO, Annakaisa and HANKE, Magda-Viola. Overexpression of BpMADS4 from silver birch (Betula pendula Roth.) induces early-flowering in apple (Malus $x$ domestica Borkh.). Plant Breeding, April 2007, vol. 126, no. 2, p. 137-145.

FLADUNG, Matthias and AHUJA, M. Raj. Excision of the maize transposable element Ac in periclinal chimeric leaves of 35S-Ac-rolC transgenic aspen-Populus. Plant Molecular Biology, April 1997, vol. 33, no. 6, p. 1097-1103.

HAMILTON, Andrew J.; BROWN, Stephen; YUANHAI, Han; ISHIZUKA, Masakatsu; LOWE, Alex; SOLIS, Angel-Gabriel A. and GRIERSON, Don. A transgene with repeated DNA causes high frequency, post-transcriptional suppression of ACC-oxidase gene expression in tomato. Plant Journal, September 1998, vol. 15, no. 6, p. 737-746.

HOENICKA, Hans and FLADUNG, Matthias. Biosafety in Populus spp. and other forest trees: from non-native species to taxa derived from traditional breeding and genetic engineering. Trees-Structure and Function, March 2006, vol. 20, no. 2, p. 131-144.

GARTLAND, Kevan M.A.; CROW, Robert M.; FENNING, Trevor $M$. and GARTLAND, Jill S. Genetically modified trees: production, properties, and potential. Journal of Arboriculture, September 2003, vol. 29, no. 5, p. 259-266.

LECHTENBERG, Berthold; SCHUBERT, Daniel; FORSBACH, Alexandra; GILS, Mario and SCHMIDT, Renate. Neither inverted repeat T-DNA configurations nor arrangements of tandemly repeated transgenes are sufficient to trigger transgene silencing. Plant Journal, May 2003, vol. 34, no. 4, p. 507-517.

MARENKOVA, T.V. and DEINEKO, E.V. A change in the stability of marker nptII and uidA gene expression in transgenic tobacco plants. Russian Journal of Genetics, May 2006, vol. 42, no. 5, p. 518-525.

MATSUDA, Narumi; GAO, Mei; ISUZUGAWA, Kanji; TAKASHINA, Tadashi and NISHIMURA, Koichi. 
Development of an Agrobacterium-mediated transformation method for pear (Pyrus communis L.) with leaf-section and axillary shoot-meristem explants. Plant Cell Reports, April 2005, vol. 24, no. 1, p. 45-51.

MATTHEWS, Helena; DEWEY, Valerie; WAGONER, Wendy and BESTWICK, Richard K. Molecular and cellular evidence of chimaeric tissues in primary transgenics and elimination of chimaerism through improved selection protocols. Transgenic Research, March 1998, vol. 7, no. 2, p. 123-129.

MAXIMOVA, Siela N.; DANDEKAR, Abhaya M. and GUILTINAN, Mark J. Investigation of Agrobacteriummediated transformation of apple using green fluorescent protein: high transient expression and low stable transformation suggest that factors other than T-DNA transfer are rate-limiting. Plant Molecular Biology, June 1998, vol. 37, no. 3, p. 549-559.

MELANDER, Margareta; KAMNERT, Iréne; HAPPSTADIUS, Ingrid; LILJEROTH, Erland and BRYNGELSSON, Tomas. Stability of transgene integration and expression in subsequent generations of doubled haploid oilseed rape transformed with chitinase and $\beta$-1,3-glucanase genes in a double-gene construct. Plant Cell Reports, September 2006, vol. 25, no. 9, p. 942952.

METTE, M.F.; AUFSATZ, W.; VAN DER WINDEN, J.; MATZKE, M.A. and MATZKE, A.J. Transcriptional silencing and promoter methylation triggered by doublestranded RNA. EMBO Journal, October 2000, vol. 19, no. 19, p. 5194-5201.

MEZA, Trine J.; STANGELAND, Biljana; MERCY, Inderjit S.; SKARN, Magne; NYMOEN, Dag A.; BERG, Anita; BUTENKO, Melinka A.; HAKELIEN, Anne-Mari; HASLEKAS, Camilla; MEZA-ZEPEDA, Leonardo A. and AALEN, Reidunn B. Analyses of single-copy Arabidopsis T-DNA-transformed lines show that the presence of vector backbone sequences, short inverted repeats and DNA methylation is not sufficient or necessary for the induction of transgene silencing. Nucleic Acids Research, August 2002, vol. 30, no. 20, p. 4556-4566.

MITTELSTEN-SCHEID, Ortrun; PASZKOWSKI, Jerzy and POTRYKUS, Ingo. Reversible inactivation of a transgene in Arabidopsis thaliana. Molecular and General Genetics, August 1991, vol. 228, no. 1-2, p. 104-112.

MUSKENS, Mariëlle W.M.; VISSERS, Adriënne P.A.; MOL, Joseph N.M. and KOOTER, Jan M. Role of inverted DNA repeats in transcriptional and post-transcriptional gene silencing. Plant Molecular Biology, June 2000, vol. 43, no. 2-3, p. 243-260.

OLBRICHT, K.; PLASCHIL, Sylvia and POHLHEIM, Frank. Causes of flower colour patterns with a focus on chimerical patterns. In: SILVA, Jaime Teixeira da ed.
Floriculture, Ornamental and Plant Biotechnology: Advances and Topical Issues. Global Science Books, 2006, vol. 1, p. 311-319.

PARK, Sung H.; ROSE, Susan C.; ZAPATA, Cecilia; SRIVATANAKUL, Metinee and SMITH, Roberta $H$. Cross-protection and selectable marker genes in plant transformation. In Vitro Cellular and Developmental

Biology-Plant, April-June 1998, vol. 34, no. 2, p. 117-121.

POETHIG, Scott. Genetic mosaics and cell lineage analysis in plants. Trends in Genetics, August 1989, vol. 5, no. 8, p. 273-277.

REIM, Stefanie and HANKE, Viola. Investigation on stability of transgenes and their expression in transgenic apple plants (Malus x domestica Borkh.). Acta Horticulturae, December 2004, vol. 1, p. 419-424.

REIM, Stefanie; FLACHOWSKY, Henryk; MICHAEL, Maria and HANKE, Magda-Viola. Assessing gene flow in apple using a descendant of Malus sieversii var. sieversii $\mathrm{f}$. niedzwetzkyana as an identifier for pollen dispersal. Environmental Biosafety Research, April-June 2006, vol. 5, no. 2, p. 89-104.

RUGINI, E.; CARICOTA, G.; MUGANU, M.; TARATUFOLO, C.; CAVILLI, M. and CAVILLI, C. Genetic stability and agronomic evaluation of six-year-old transgenic kiwi plant for rolABC and rolB genes. Acta Horticulturae, 1997, vol. 1, p. 609-610.

SCHMÜLLING, Thomas and SCHELL, Jeff. Transgenic tobacco plants regenerated from leaf disks can be periclinal chimeras. Plant Molecular Biology, February 1993, vol. 21, no. 4, p. 705-708.

SCHUBERT, Daniel; LECHTENBERG, Berthold; FORSBACH, Alexandra; GILS, Mario; BAHADUR, Sultan and SCHMIDT, Renate. Silencing in Arabidopsis TDNA transformants: the predominant role of a genespecific RNA sensing mechanism versus position effects. The Plant Cell, October 2004, vol. 16, no. 10, p. 25612572.

SZYMKOWIAK, Eugene J. and SUSSEX, Ian M. What chimeras can tell us about plant development. Annual Review of Plant Physiology and Plant Molecular Biology, June 1996, vol. 47, p. 351-376.

TIAN, Hui-Cheng and MARCOTRIGIANO, Michael. Origin and development of adventitious shoot meristems initiated plant chimeras. Developmental Biology, January 1993, vol. 155, no. 1, p. 259-269.

ULIAN, E.C.; MAGILL, J.M.; MAGILL, C.W. and SMITH, R.H. DNA methylation and expression of NPT II in transgenic petunias and progeny. Theoretical and Applied Genetics, June 1996, vol. 92, no. 8, p. 976-981. 
VAN LEEUWEN, Wessel; RUTTINK, Tom; BORSTVRENSSEN, Antoinette W.M.; VAN DER PLAS, Linus H.W. and VAN DER KROL, Alexander R. Characterization of position-induced spatial and temporal regulation of transgene promoter activity in plants. Journal of Experimental Botany, May 2001, vol. 52, no. 358, p. 949-959.

WATERHOUSE, Peter M.; GRAHAM, Michael W. and WANG, Ming-Bo. Virus resistance and gene silencing in plants can be induced by simultaneous expression of sense and antisense RNA. Proceedings of the National Academy of Sciences of the United States of America, November 1998, vol. 95, no. 23, p. 13959-13964.

YANG, Guojun; LEE, Yeon-Hee; JIANG, Yiming; KUMPATLA, Siva P. and HALL, Timothy C. Organization, not duplication, triggers silencing in a complex transgene locus in rice. Plant Molecular Biology, June 2005, vol. 58, no. 3, p. 351-366. 